\title{
Genetic variation and reproductive success of road verge populations of the rare shrub Grevillea barklyana (Proteaceae)
}

\author{
PATRICIA M. HOGBIN*, DAVID J . AYRE \& ROBERT J . WHELAN \\ Department of Biological Sciences, University of Wollongong, Northfields Avenue, Wollongong, NSW 2522, \\ Australia
}

\begin{abstract}
Road verge remnant native vegetation often provides a last refuge for many endangered plant species. However, the value of road verge populations is often questioned because their relatively small size and isolation is expected to reduce both their reproductive potential and their genotypic diversity. We assessed the fitness, genetic variability and links with other populations of small, disjunct and highly disturbed road verge populations of the rare Australian shrub Grevillea barklyana. We found that a set of three road verge populations produced significantly more inflorescences and seed than three nearby nonverge populations. Using three random amplified polymorphic DNA (RAPD) primers, we detected similar levels of genetic variability within and among road verge and nonverge populations. We detected a total of 23 polymorphic marker bands, which allowed us to assign a unique phenotype to each of 60 surveyed plants. AMOVA revealed that only 3.3 per cent of the total variability detected was attributable to variation between the two groups of populations. The majority ( 80 per cent) of variation occurred among individuals within populations, and 16.7 per cent occurred among populations within each population type. Surprisingly, this pattern of variation is similar to results reported for obligatorily outcrossing species. We conclude that our three road verge populations of $G$. barklyana have relatively great conservation value, as all were apparently as fecund and as genetically diverse as conspecific nonverge populations.
\end{abstract}

Keywords: conservation biology, habitat fragmentation, population genetics, remnant vegetation, random amplified polymorphic DNA, reproductive success.

\section{Introduction}

Habitat destruction is one of the greatest threats to the conservation of biodiversity. Within Australia, the majority of plant extinctions have arisen from habitat destruction associated with grazing and agriculture (Leigh \& Briggs, 1992). For some plant species, land clearing may result in rapid extinction through total destruction of most of the available habitat. In others, longer term viability may be reduced as a direct result of extreme habitat fragmentation, even if patches of habitat remain. A number of studies have investigated the consequences of habitat fragmentation upon animal populations (e.g. Tscharntke, 1992; Kattan et al., 1994;

*Present address and correspondence: Division of Botany and Zoology, Australian National University, Canberra, ACT 0200, Australia. E-mail: tricia.hogbin@anu.edu.au
Johannesen \& Ims, 1996; Wauters et al., 1996), but surprisingly few studies have investigated either the demographical or genetic consequences of habitat fragmentation upon the viability of plant populations (see Turner \& Corlett, 1996; Young et al., 1996).

Population fragmentation may produce an increased susceptibility to both demographical and genetic hazards, which may interact further to promote high extinction probabilities (Gilpin \& Soulé, 1986). It is commonly perceived that, in addition to demographical uncertainty, genetic uncertainties will also contribute, and in the long term may even be the most significant contributor, to the risk of extinction by the reduction in genetic diversity caused by increases in inbreeding and genetic drift (Charlesworth \& Charlesworth, 1987; Ellstrand \& Elam, 1993). The evolutionary significance of a reduction in genetic diversity remains uncertain 
(Charlesworth \& Charlesworth, 1987). On theoretical grounds, genetic variation is considered vital for allowing both short-term adaptation to environmental fluctuations and long-term evolutionary change (Frankel \& Soulé, 1981; Barrett \& Kohn, 1991; Schaal et al., 1991).

In many extensively cleared regions of Australia, the only surviving fragments of native vegetation occur along road verges (Leigh \& Briggs, 1992). These fragments are the only refuges for some endangered plant species (Breckwoldt, 1990). Approximately 25 per cent of endangered plant species in Australia are currently confined to remnant vegetation along road verges (Leigh \& Briggs, 1992).

The shrubs Grevillea barklyana sp. macleayana F. Muell. ex Benth. (Proteaceae) provides a model system in which to investigate the consequences of habitat fragmentation on the reproductive success and genetic variation of road verge populations. This rare and restricted species (Briggs \& Leigh, 1996) occurs only in south-eastern Australia along the south coast of New South Wales. Extant populations are typically small, consisting of five to 150 individuals (personal observation), and most occur on road verges and in other disturbed areas, such as gravel pits and quarries. The species has no obvious adaptations for seed dispersal, and soil disturbance or fire is required for seed germination (Edwards \& Whelan, 1995). Such small size and potential isolation of populations suggest that they may exhibit reduced genetic diversity. However, the level of genetic diversity within and among these populations may also be influenced by their breeding system. Grevillea barklyana is pollinated by nectar-feeding birds, such as wattle-birds and honey-eaters (Vaughton, 1995), but its mating system is flexible. Experimental hand-pollinations have shown similar levels of seed-set for both selfed and outcrossed pollen (Harriss \& Whelan, 1993). Ayre et al. (1994) used allozyme data for natural progeny arrays and found that one of four populations was almost exclusively outcrossed, whereas the other three populations were almost completely selfed.

Ayre et al. (1994) found that only two out of 25 allozyme loci were variable; hence, allozyme electrophoresis appears unsuitable for the quantitative estimation of variation within and among populations. In this study, we used the more sensitive technique of random amplified polymorphic DNA (RAPD) analysis (Williams et al., 1990) to quantify genetic variation within and among road verge and nonverge populations. We then combined these data with demographical analyses to assess the conservation value of road verge populations of $G$. barklyana.

\section{Materials and methods}

\section{Study sites}

Both the demographic and genetic studies were carried out on six populations within Beecroft Peninsula on the northern side of Jervis Bay, NSW, Australia $\left(35^{\circ} 03^{\prime} \mathrm{S}, 150^{\circ} 48^{\prime} \mathrm{E}\right)$. Three of the sites occurred directly adjacent to roads and the other three did not. In the road verge sites, G. barklyana occurred only within $3 \mathrm{~m}$ of the road. The nonverge sites were at least $70 \mathrm{~m}$ from any form of detectable disturbance, such as a road, walking track or quarry.

\section{Genetic study}

RAPD markers were used to investigate the distribution of genetic variation within and among the set of three road verge and three nonverge populations. RAPD markers are now widely used for investigating the distribution of genetic variation within and among plant populations (e.g. Dawson et al., 1993; Huff et al., 1993; Antonius \& Nybom, 1994; Nesbitt et al., 1995).

\section{Population sampling and template DNA isolation}

A mature leaf was collected from each of 10 randomly selected individuals within each population. Template DNA was then isolated from a homogenate prepared by grinding $0.1 \mathrm{~g}$ of leaf tissue in liquid nitrogen using $0.75 \mathrm{~mL}$ of extraction buffer (2 per cent $\mathrm{CTAB}, 1.4 \mathrm{M} \mathrm{NaCl}, 10$ per cent

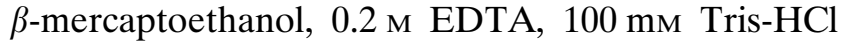
and 2 per cent PVP). The solution was vortexed and incubated at $65^{\circ} \mathrm{C}$ for $30 \mathrm{~min}$. Then, $0.5 \mathrm{~mL}$ of chloroform-isoamyl alcohol (100:1) was added, and the tubes were subjected to $5 \mathrm{~min}$ of hand inversions and $25 \mathrm{~min}$ on a gentle shaker. After centrifugation at $12000 \mathrm{~g}$ for $20 \mathrm{~min}$ at $4^{\circ} \mathrm{C}$, the aqueous phase was transferred to a fresh $1.5 \mathrm{~mL}$ microfuge tube to which $500 \mu \mathrm{L}$ of chilled isopropanol (100 per cent) (isoamyl alcohol) was added. After being left at $-20^{\circ} \mathrm{C}$ overnight, the samples were centrifuged at $12000 \mathrm{~g}$ for $20 \mathrm{~min}$, and the supernatant was removed leaving the DNA pellet at the base of the tube. The pellets were washed in 70 per cent ethanol for $1 \mathrm{~h}$ at $-20^{\circ} \mathrm{C}$. After centrifugation at $12000 \mathrm{~g}$ for $5 \mathrm{~min}$, the supernatant was carefully removed, and the DNA pellet was dried in a vacuum drier and resuspended in $25 \mu \mathrm{L}$ of $\mathrm{TE}$ buffer. The DNA 
content of each sample was measured using fluorescence spectrophotometry (Ausubel et al., 1989).

\section{RAPD polymerase chain reaction procedure}

The Williams et al. (1990) technique for the generation of RAPD markers was modified to include a primer stabilization step $\left(60^{\circ} \mathrm{C}\right)$ developed by Griskaitis (1995), which stabilizes the primer/template duplex during heating to DNA extension temperatures. We found that this increased scorable variation, tolerance to DNA concentration variation and reproducibility. In addition, the annealing temperature was optimized. Total reaction volumes of $25 \mu \mathrm{L}$ were used with final concentrations of: $10 \times$ Taq reaction buffer (Promega), $25 \mathrm{mM} \mathrm{MgCl}_{2}, 10 \mathrm{~mm}$ decamer primer, $25 \mathrm{~mm}$ dNTP, $5 \mathrm{U}_{\mu} \mathrm{L}^{-1}$ Taq polymerase (Promega) and 2 ng of template DNA. The reactions were overlaid with mineral oil and amplification was performed as follows: initial 3 min denaturation at $94^{\circ} \mathrm{C} ; 60$ cycles of $0.1 \mathrm{~min}$ at $94^{\circ} \mathrm{C}$, annealing at $40^{\circ} \mathrm{C}$ for $0.3 \mathrm{~min}$, stabilization at $60^{\circ} \mathrm{C}$ for $2.3 \mathrm{~min}$, extension at $74^{\circ} \mathrm{C}$ for $2.3 \mathrm{~min}$. An additional 8-min period for extension followed the last cycle.

Twenty 10-mer primers (Operon Kit F and Y) were evaluated for suitability in an initial survey. Of these, the primers OPF-13, OPF-08 and OPY-17 were found to reveal sufficient numbers of polymorphic bands that were reproducible and readily scored. These three primers were used to generate RAPD profiles for all 60 individuals sampled.

DNA of previously amplified samples and a negative control were included in all thermocycling assays to check the reproducibility of amplification product profiles between reactions and to verify the absence of contamination or nonspecific amplification.

\section{Fragment visualization and scoring}

We resolved amplification products electrophoretically in 0.6 per cent agarose and 1 per cent Synergel $^{\mathrm{TM}}$ gels, using $0.5 \times \mathrm{TBE}$ buffer at $110 \mathrm{~V}$ for $1.5-2.5 \mathrm{~h}$ (depending on primer). Fragments were then visualized by staining with ethidium bromide and photographed on an ultraviolet transilluminator. Each photograph was scanned using a Bio-Rad GS-670 imaging densitometer. The intensity of each band was determined using MOLECULAR ANALYST software, version 2.1 (Bio-Rad), and only distinct and intense bands were scored. Amplification bands were scored as present or absent. Monomorphic markers were then excluded from the data set.

\section{Statistical analysis}

A pairwise Euclidean distance matrix (Excoffier et al., 1992; Huff et al., 1993; Peakall et al., 1995) was generated from the presence/absence data using the program RAPDistance (Armstrong et al., 1994). Variance components attributable to among individuals within populations, among populations within groups (i.e. road verge and nonverge populations) and between groups were estimated from the distance matrix by an analysis of molecular variance (AMOVA) using the program winAMOVA (Excoffier $e t$ al., 1992). We also ran separate analyses for road verge and nonverge populations only.

\section{Reproductive potential}

To assess the reproductive potential of populations, we counted the number of inflorescences and seeds on seven individuals within each population at 3-week intervals from April to September 1995. The seven plants were selected at random at each census date. The size of each plant was recorded by measuring the height $(h)$, widest width $(w 1)$ and width at $90^{\circ}$ to the widest width (w2). These values were then used to determine reproductive output per unit of crown volume $(\pi . h . w 1 . w 2 / 6)$. The numbers of inflorescences and seeds and the numbers per unit of crown volume were compared using a paired $t$-test after $\log _{10}$ transformation. The outcome of the analysis after correction for plant volume was similar to that of the true values (results not shown).

\section{Results}

\section{Genetic variation}

RAPD profiles The three primers OPF-13, OPF-08 and OPY-17 revealed sufficient variation to assign a unique phenotype to each of the 60 individuals sampled (Table 1). We found that although no markers were unique to any one population, two markers varied significantly among populations $\left(\chi_{5}^{2}=30\right.$ and $\left.36, P<0.001\right)$, and within populations the frequencies of these two markers ranged from apparent fixation (present in all 10 individuals tested) to extreme rarity (present in only one or two of the 10 individuals tested).

Analysis of molecular variance Our hierarchical analysis of molecular variance (AMOVA) revealed that the majority of variation ( 80 per cent) was attributable to variation among individuals within populations (Table 2). A further 16.7 per cent of the 
Table 1 Attributes of oligonucleotide primers used for generating RAPD markers from 60 individuals of Grevillea barklyana sampled from six populations on Beecroft Peninsula

\begin{tabular}{lccc}
\hline Primer & $\begin{array}{c}\text { Number of } \\
\text { monomorphic bands }\end{array}$ & $\begin{array}{c}\text { Number of } \\
\text { polymorphic bands }\end{array}$ & $\begin{array}{c}\text { Number of } \\
\text { distinct phenotypes }\end{array}$ \\
\hline OPF-13 & 5 & 5 & 12 \\
OPF-08 & 4 & 8 & 24 \\
OPY-17 & 1 & 10 & 47 \\
Total & 10 & 23 & 60 \\
\hline
\end{tabular}

variance was attributable to variation among populations within groups, and only 3.3 per cent was attributable to variation between road verge and nonverge populations. The patterns of variability within and among populations were similar in the three road verge and the three nonverge populations (Table 2).

\section{Reproductive potential}

Our comparison of inflorescence and seed production among population types revealed that road verge populations possessed a higher reproductive potential than nonverge populations. Mean crown volume did not differ significantly between the two groups of populations $\left(2.42 \pm 0.76 \mathrm{~m}^{3}\right.$ and $1.69 \pm$ $0.24 \mathrm{~m}^{3}$ (mean $\pm \mathrm{SE}$ ) for road verge and nonverge, respectively; $t_{152}=1.013 ; P=0.313$ ), and population phenologies were synchronous throughout the study period. Nevertheless, we found that inflorescence production varied markedly and significantly between the two sets of populations, and road verge populations were on average 2.5 times more productive $(4943 \pm 2648$ vs. $1998 \pm 757$ (mean \pm SE); $\left.t_{4}=3.37, P<0.05\right)$. Road verge populations also produced on average 3.9 times more seed than nonverge populations $(627 \pm 478$ vs. $161 \pm 48$ $($ mean $\left.\pm \mathrm{SE}) ; t_{4}=2.49, P<0.025\right)$.

\section{Discussion}

This study, through the use of a combination of demographical and genetic methodologies, highlights the conservation value of road verge populations of the threatened shrub G. barklyana. Road verge plants displayed potentially greater reproductive success through both male and female function than nonverge plants. Moreover, we found that local populations in road verge and nonverge sites display almost identical levels of genetic diversity with little evidence of population subdivision. Both types of local populations therefore appear to be strongly interconnected by gene flow and may contribute similarly to the overall gene pool or effective size of the breeding population of this vulnerable species.

\section{Genetic variation of road verge populations}

Contrary to theoretical expectations, the small and isolated road verge populations of $G$. barklyana were

Table 2 Analysis of molecular variance (AMOVA) for 60 individuals of Grevillea barklyana, using 23 RAPD markers

\begin{tabular}{lrcccr}
\hline Source of variation & & & & $\begin{array}{c}\text { Variance } \\
\text { component }\end{array}$ & $\begin{array}{r}\% \text { Total } \\
\text { variance }\end{array}$ \\
\hline Road verge vs. non-road verge & 1 & 12.13 & 12.13 & $0.11^{*}$ & 3.35 \\
Populations within groups & 4 & 34.8 & 8.7 & $0.58^{*}$ & 16.73 \\
Individuals within populations & 54 & 152 & 2.81 & $2.81^{*}$ & 80.02 \\
Non-road verge population & 2 & 14 & 7 & $0.43^{*}$ & 13.74 \\
Individuals within populations & 27 & 72.9 & 2.7 & $2.70^{*}$ & 86.26 \\
Road verge populations & 2 & 20.8 & 10.4 & $0.75^{*}$ & 20.32 \\
Individuals within populations & 27 & 79.1 & 2.9 & $2.92^{*}$ & 78.68 \\
\hline
\end{tabular}

*The probability of obtaining a more extreme component estimate by chance alone is $<0.004$. 
found to be both equally diverse and genetically similar to the nonverge populations. We found that, within $G$. barklyana, genetic variation is partitioned similarly to other outcrossed species with high levels of interpopulation gene flow (Huff et al., 1993; Nesbitt et al., 1995; Rossetto et al., 1995). Of the total variation detected, 80 per cent occurred among individuals within populations. Approximately 17 per cent of the total variation occurred among populations within groups (i.e. road verge and nonverge populations). These data imply that extensive gene flow is occurring among both types of populations or that gene flow among populations was once occurring and that populations have not been isolated long enough for specific genes to be gained or lost. This study contrasts with the findings of Ayre et al. (1994), in which allozyme data suggested that three of four $G$. barklyana populations currently exhibit high levels of inbreeding. However, Ayre et al. worked only with newly produced seeds, whereas our present study examined adult plants. These contrasting results may, therefore, reflect a dramatic change in the mating system of $G$. barklyana since the establishment of the current adult plants or temporal variability in the nature of the realized mating system within these populations.

\section{Reproductive potential of road verge populations}

Measurement of fitness in natural populations is notoriously difficult (Primack \& Kang, 1989), and this problem is compounded when dealing with organisms such as hermaphroditic, perennial plants, which should have multiple reproductive episodes and separate male and female functions. In our study, road verge plants of $G$. barklyana produced both significantly more inflorescences (an indicator of both male and female reproductive potential) and seeds (a measure of female reproductive output) than nonverge populations. Elevated reproductive output has also been reported in road verge populations of the Australian shrubs Banksia hookeriana and B. menziesii (Lamont et al., 1994a,b). In contrast, small and isolated road verge populations of the endangered shrub Banksia goodii were found to possess drastically reduced seed-set, possibly as a consequence of a reduction and/or change in pollinator activity (Lamont et al., 1993). Assessment of the reproductive output of road verge vegetation should, therefore, occur on a case-by-case basis.

Several factors may contribute to the apparently higher reproductive output of road verge plants. Road verges may possess an increased water and mineral nutrient availability, induced by run-off from the road (Lamont et al., 1994a,b). Such additional water and nutrients would lead to increased vegetative and reproductive growth (Zimmerman \& Pyke, 1988; Lamont et al., 1991). Road verge plants may encounter less competition for access to water and nutrients because the road apron is free of large plants and may thus be able to exploit resources that would not otherwise be available to them in a non-verge environment. The greater inflorescence production of road verge plants may lead to higher seed set as a result of higher rates of visitation by nectarivorous birds attracted by the greater intensity of inflorescences (Lamont \& van Leeuwen, 1988).

\section{Conservation implications}

Interpretation of the evolutionary or ecological significance of our results rests on a number of assumptions, of which the most critical is that our short-term study provides a realistic picture of continuing patterns of reproduction and gene flow within verge and nonverge populations. The available evidence is clearly sufficient to demonstrate the potential value of road verge populations as a resource that may buffer the species against further decline. However, the apparent success of road verge plants may mean little if there is no current gene flow or if germination and recruitment are lower in road verge than nonverge populations. Rigorous assessment of their likelihood of persistence and contribution to the species gene pool will require a long-term study that includes documentation of the source and frequency of recruitment and compares the fitness of these two groups of plants through the assessment of (1) the fate of seed monitored through at least one generation; and (2) male function judged via measurement of gene flow within and among populations.

Current support for the conservation of road verge communities is typically based on the realization that verges often contain the last remaining stands of native vegetation in a disturbed landscape and often contain populations of endangered plant species. Typically, these populations are thought to be even more vulnerable and potentially less worthwhile targets for conservation than apparently 'pristine' populations. However, the present study suggests that, even though road verge populations may be small and highly fragmented, they may still retain links with neighbouring populations via gene flow and are thus able to maintain considerable genetic variability. Such gene flow among these small remnant populations would be highly advantageous, as it would act against the detrimental effects

(c) The Genetical Society of Great Britain, Heredity, 80, 180-186. 
of inbreeding depression and genetic drift (Ellstrand \& Elam, 1993), thus increasing effective population size.

\section{Acknow ledgements}

We thank Al Griskaitis for technical assistance and Rod Peakall, Marita Sydes and Peter O'Hanlon for reviewing a draft of this manuscript. This research was supported by an ARC small grant and the University of Wollongong's Australian Flora and Fauna Research Centre. This is publication number 156 from the Ecology and Genetics Group of the University of Wollongong.

\section{References}

ANTONIUS, K. AND NYBOM, H. 1994. DNA fingerprinting reveals significant amounts of genetic variation in a wild raspberry Rubus idaeus population. Mol. Ecol., 3, $177-180$.

ARMSTRONG, J., GIBBS, A., PEAKAll, R. AND WEILler, G. F. 1994. RAPDistance: Random Amplified Polymorphic DNA Analysis. Computer program distributed by the Australian National University. http://life.anu.edu.au/molecular/software/rapd.html.

Ausubel, F. M., BRENT, R., KingSTON, R. E., MOORE, D. D., SMITH, J. A., SEIDMAN, J. G. AND STRUHL, K. 1989. Current Protocols in Molecular Biology. Wiley Interscience, New York.

AYRE, D. J., WHELAN, R. J. AND REID, A. 1994. Unexpectedly high levels of selfing in the Australian shrub Grevillea barklyana (Proteaceae). Heredity, 72, 168-174.

BARRETT, S. C. H. AND KOHN, J. R. 1991. Genetic and evolutionary consequences of small population size in plants: implications for conservation. In: Falk, D. A. and Holsinger, K. E. (eds) Genetics and Conservation of Rare Plants, pp. 3-30. Oxford University Press, New York.

BRECKWOLDT, R. 1990. Living Corridors: Conservation and Management of Roadside Vegetation. Greening Australia, Canberra.

BRIGgs, J. D. AND LEIGH, J. H. 1996. Rare or Threatened Australian Plants. CSIRO, Australia.

CHARLESWORTH, D. AND CHARLESWORTH, B. 1987. Inbreeding depression and its evolutionary consequences. Ann. Rev. Ecol. Syst., 18, 237-268.

DAWSON, I. K., CHALMERS, K. J., WAUGH, R. AND POWELL, W. 1993. Detection and analysis of genetic variation in Hordeum spontaneum populations from Israel using RAPD markers. Mol. Ecol., 2, 151-159.

EDWARDS, w. AND WHELAN, R. 1995. The size, distribution and germination requirements of the soil-stored seedbank of Grevillea barklyana (Proteaceae). Aust. J. Ecol., 20, 548-555.

Ellstrand, N. C. AND ElAM, D. R. 1993. Population genetic consequences of small population size: implica- tions for plant conservation. Ann. Rev. Ecol. Syst., 24, 217-242.

EXCOFFIER, L., SMOUSE, P. E. AND QUATTRO, J. M. 1992. Analysis of molecular variance inferred from metric distances among DNA haplotypes: application to human mitochondrial DNA restriction sites. Genetics, 131, 479-491.

FRANKEL, O. H. AND SOUlÉ, M. E. 1981. Conservation and Evolution. Cambridge University Press, Cambridge.

GILPIN, M. E. AND SOULÉ, M. E. 1986. Minimum viable populations: the processes of species extinction. In: Soulé, M. E. (ed.) Conservation Biology: The Science of Scarcity and Diversity, pp. 13-34. Sinauer, Sunderland, MA.

GRISKAItis, A. 1995. The Development and Application of a Molecular Technique to Investigate Genetic Variation of a Phylopatric Ascidean at a Fine Spatial Scale. Honours Thesis, Department of Biological Sciences, University of Wollongong.

HARRISS, F. AND WHELAN, R. J. 1993. Selective fruit abortion in Grevillea barklyana (Proteaceae). Aust. J. Bot., 41, 499-509.

HUFF, D. R., PEAKAll, R. AND SMOUSE, P. E. 1993. RAPD variation within and among populations of outcrossing buffalograss (Buchloe dactyloides (Nutt.) Engelm). Theor. Appl. Genet., 86, 927-934.

JOHANNESEN, E. AND IMS, R. A. 1996. Modelling survival rates: habitat fragmentation and destruction in root vole experimental populations. Ecology, 77, 1196-1209.

KATTAN, G. H., ALVAREZ-LOPEZ, H. AND GIRALDO, M. 1994. Forest fragmentation and bird extinctions San-Antonio 80 years later. Conserv. Biol., 8, 138-146.

LAMONT, B. B. AND VAN LEEUWEN, s. J. 1988. Seed production and mortality in a rare Banksia species. J. Appl. Ecol., 25, 551-559.

LAMONT, B. B., CONNELl, S. W. AND BERGL, S. M. 1991. Seed bank and population dynamics of Banksia cuneata: the role of time, fire and moisture. Bot. Gaz., 152, 114-122.

LAMONT, B. B., KLINKHAMER, P. G. L. AND WITKOWSKI, E. T. F. 1993. Population fragmentation may reduce fertility to zero in Banksia goodii - a demonstration of the Allee effect. Oecologia, 94, 446-450.

LAMONT, B. B., REES, R. G., WITKOWSKI, E. T. F. AND whitten, v. A. 1994a. Comparative size, fecundity and ecophysiology of roadside plants of Banksia hookeriana. J. Appl. Ecol., 31, 137-144.

LAMONT, B. B., WHITTEN, V. A., WITKOWSKI, E. T. F., REES, R. G. AND ENRIGHT, N. J. 1994b. Regional and local (road verge) effects on size and fecundity in Banksia menziesii. Aust. J. Ecol., 19, 197-205.

LeIgH, J. H. AND BRIGgs, J. D. 1992. Threatened Australian Plants. Overview and Case Studies. ANPWS, Canberra.

NESBITT, K. A., POTTS, B. M., VAILlAnCOURT, R. E., WEST, A. K. AND REID, J. B. 1995. Partitioning and distribution of RAPD variation in a forest tree species, Eucalyptus globulus (Myrtaceae). Heredity, 74, 628-637.

PEAKAll, R., SMOUSE, P. E. AND HUFF, D. R. 1995. Evolutionary implications of allozyme and RAPD variation in 
diploid populations of buffalograss (Buchloe dactyloides (Nutt.) Engelm). Mol. Ecol., 4, 135-147.

PRIMACK, R. B. AND KANG, H. 1989. Measuring fitness and natural selection in wild plant populations. Ann. Rev. Ecol. Syst., 20, 367-396.

ROSSETTO, M., WEAVER, P. K. AND DIXON, K. W. 1995. Use of RAPD analysis in devising conservation strategies for the rare and endangered Grevillea scapigera (Proteaceae). Mol. Ecol., 4, 321-329.

SCHAAL, B. A., O'KANE, S. L., JR AND ROGSTAD, S. H. 1991. DNA variation in plant populations. Trends Ecol. Evol., 6, 329-333.

TSChARntKe, T. 1992. Fragmentation of Phragmites habitats, minimum viable population size, habitat suitability, and local extinction of moths, midges, flies, aphids, and birds. Conserv. Biol., 6, 530-536.

TURNER, I. M. AND CORLETT, R. T. 1996. The conservation value of small, isolated fragments of lowland tropical rain forest. Trends Ecol. Evol., 11, 330-333.
VAughton, G. 1995. No evidence for selective fruit abortion in the Australian shrub Grevillea barklyana (Proteaceae). Int. J. Pl. Sci., 156, 417-424.

WAUTERS, L. A., DHONDT, A. A., KNOTHE, H. AND PARKIN, D. т. 1996. Fluctuating asymmetry and body size as indicators of stress in Red squirrel populations in woodland fragments. J. Appl. Ecol., 33, 735-740.

WILLIAMS, J. G. K., KUBELIK, A. R., LIVAK, K. J., RAFALSKI, J. A. AND TINGEY, s. v. 1990. DNA polymorphisms amplified by arbitrary primers are useful as genetic markers. Nucl. Acids Res., 18, 6531-6535.

YOUNG, A., BOYLE, T. AND BROWN, T. 1996. The population genetic consequences of habitat fragmentation for plants. Trends Ecol. Evol., 11, 413-418.

ZIMMERMAN, M. AND PYKE, G. H. 1988. Experimental manipulation of Polemonium foliosissimum: effects on subsequent nectar production, seed production and growth. J. Ecol., 76, 777-789. 